\title{
Comparison of anthropometric indices for predicting the risk of metabolic syndrome in older adults
}

\author{
SARA KHOSRAVIAN ${ }^{1}$, MOHAMMAD ALI BAYANI ${ }^{2}$, SEYED REZA HOSSEINI ${ }^{3}$, \\ ALI BIJANI ${ }^{4}$, SIMIN MOUODI ${ }^{3}$, REZA GHADIMI ${ }^{3 *}$ \\ ${ }^{1}$ Student Research Committee, Babol University of Medical Sciences, Babol, Iran \\ ${ }^{2}$ Department of Internal Medicine, Babol University of Medical Sciences, Babol, Iran \\ ${ }^{3}$ Social Determinants of Health Research Center, Health Research Institute, \\ Babol University of Medical Sciences, Babol, Iran \\ ${ }^{4}$ Non-Communicable Pediatric Research Center, Health Research Institute, \\ Babol University of Medical Sciences, Babol, Iran
}

\begin{abstract}
Background. The prevalence of obesity and metabolic syndrome (MetS) is increasing, worldwide. Using a simple, efficient and reliable tool for predicting MetS is an essential approach in preventive health programs. The aim of this study was to compare the different anthropometric indices in predicting metabolic syndrome in older adults.

Methods. This cross-sectional study is a part of the Amirkola Health and Ageing cohort Project (2011-2016). Of total, 1,488 older people aged 60-92 years were entered to the study. Medical and personal information of participants were collected by a questionnaire. After measuring the height, weight, waist circumference, hip circumference and neck circumference, body mass index, waist to hip ratio, waist to height ratio, abdominal volume index and conicity index were calculated. Independent t-test, chi-square and ROC curve were used to analyze the data.

Results. Based on ATPIII-2005 diagnostic criteria, the prevalence of metabolic syndrome was $71.57 \%$. The prevalence in female was higher than male. All of examined anthropometric indices, except neck circumference $(\mathrm{p}=0.10)$, showed a significant difference in people with MetS compared to the individuals without metabolic syndrome $(\mathrm{p}<0.001)$. Waist to height ratio showed the largest area under the curve for predicting MetS $(0.786$; 95\% CI: $0.76-0.81)$ followed by BMI $(0.746 ; 95 \%$ CI: $0.71-0.77)$, AVI (0.745; 95\% CI: $0.71-0.77)$, and waist circumference $(0.743$; 95\% CI: $0.71-0.77)$.

Conclusion. Waist to height ratio was the best predictor of MetS in older adults.
\end{abstract}

Key words: metabolic syndrome, anthropometry, obesity, elderly, Body Mass Index.

\section{INTRODUCTION}

The prevalence of overweight and obesity is rapidly increasing in developing and industrial countries $[1,2]$. Unhealthy diet and physical inactivity have been presented as the main contributors to overweight and obesity [3]. Previous studies showed that overweight and obesity, total body fat, and central distribution of body fat are closely related to the risk of diabetes, hypertension, hyperlipidemia, and cardiovascular disease $[4,5]$.

Metabolic syndrome (MetS) including visceral obesity, dyslipidemia, hyperglycemia, and hypertension has turned to one of the major challenges to public health, worldwide [6-8]. The syndrome was internationally defined for the first time in 1998 by the World Health Organization [9]. In 2001, Adult Treatment Panel III (ATPIII) released another definition for this syndrome based on the five measurable criteria (triglycerides, fasting plasma glucose, HDL, blood pressure, and waist circumference) [6].
Although imaging procedures such as dualenergy x-ray absorptiometry (DEXA), magnetic resonance imaging (MRI), and computed tomography (CT) scan are gold standard tools for assessing body fat $[10,11]$, they are not applicable in all situations and are much expensive. In epidemiologic and clinical studies, anthropometric indices such as body mass index (BMI), waist and neck circumferences, and similar measures are more valuable in practice than medical imaging because they are less timeconsuming and have low costs [12]. Currently, $\mathrm{BMI}$ is the most common measured index for the diagnosis of overweight and obesity [10, 13, 14]; however, it has some limitations. BMI provides no information about distribution of adipose tissue in organs, is affected by age, sex, education, etc., and cannot distinguish between fat and muscle [15]. Therefore, providing an alternative index for BMI without these limitations has been notified in recent years. Studies have shown that abdominal obesity that is assessed based on waist circumference can 
play a crucial role in the development of metabolic diseases [16]. Waist circumference provides a better estimate of visceral fat and can be used as an alternative marker for abdominal fat mass [17]. Waist-to-height ratio is another index for measurement of obesity and is used to predict metabolic risks [14]. It was also reported that waist-to-hip ratio is more important in older people than BMI or waist circumference in predicting metabolic diseases [18, 19]. Cardiometabolic risk varies in people with same waist circumference and different height and the index can modulate the effect of height [20]. Neck circumference has been reported to be more accurate than BMI, because a significant correlation exists between neck circumference and abdominal obesity. Several studies have shown that in comparison with BMI and waist circumference, neck circumference may be independently associated with metabolic risk factors $[21,22]$. Conicity Index (CI) and Abdominal Volume Index (AVI) are also new indicators of abdominal obesity and seem to be good predictors for metabolic disorders [23].

Although all these indicators can be used for assessment of obesity and metabolic diseases, the best way to predict metabolic diseases using anthropometric indices still remains controversial, because anthropometric indices are influenced by race, age, and gender; in addition to, body composition can be different in different populations and races. The aim of this study was to compare waist circumference, BMI, neck circumference, waist-toheight ratio, and waist-to-hip ratio as well as CI and AVI as predictors of metabolic diseases in elderly individuals.

\section{MATERIALS AND METHODS}

This cross-sectional study came from the Amirkola Health and Ageing cohort Project (AHAP), 2011-2016 [24]. All 1616 elderly people (aged 60 years and above) living in Amirkola, north of Iran were invited to participate in the research. They were informed about this study through a public call, as well as information on mosques and public places, and informational posters distributed throughout the region. Older adults with advanced chronic diseases such as malignancy, dementia or disabilities that prevented them to follow medical examinations and laboratory tests related to the project have been excluded. Personal and medical information of the individuals including blood pressure, previously diagnosed diseases, and current medications were collected through direct interview and physical examination. Blood pressure was measured in the sitting position, taken on the right arm with the Omron M6 digital sphygmomanometer. Anthropometric parameters including waist, neck, and hip circumference, weight and height were measured. The persons' weight was carefully measured without shoes with an accuracy of $0.1 \mathrm{~kg}$ and height in a standing position with an accuracy of $0.1 \mathrm{~cm}$. Body mass index (BMI) was calculated as weight $(\mathrm{kg}) / \operatorname{Height}^{2}(\mathrm{~m})$, and the individuals were divided into underweight, normal, overweight, and obese categories based on BMIs of $<18.5,18.5-24.9,25-29.9$, and $\geq 30 \mathrm{~kg} / \mathrm{m}^{2}$, respectively [25].

Waist circumference (WC) was measured in an area between the lowest rib and the iliac crest, in upper third and hip circumference (HC) in the most prominent point of the hip. These measurements were performed for two times, if the difference was less than $1 \mathrm{~cm}$, mean of the two measures was recorded and if the difference was more than $1 \mathrm{~cm}$, both measurements were repeated [15]. The waist-tohip ratio (WHR) was calculated as $\mathrm{WC}(\mathrm{cm}) / \mathrm{HC}(\mathrm{cm})$ and waist-to-height ratio (WHtR) as WC $(\mathrm{cm}) /$ height $(\mathrm{cm})$. Conicity Index and Abdominal Volume Index were calculated from the relationship of waist circumference with height and weight and the relationship of waist and hip circumferences according to the following formulas, respectively, $\mathrm{CI}=\mathrm{WC} /[0 / 1093 \mathrm{sqrt}$ (weight/height) $]$ and AVI was calculated as $\left[2 \mathrm{~cm} \times(\text { waist circumference })^{2}+\right.$ $\left.0.7 \mathrm{~cm} \times(\text { waist-hip circumference) })^{2}\right] / 1000$ [26]. Fasting plasma glucose, triglycerides, cholesterol, HDL, and LDL were measured through a standard method using Pars Azmoon laboratory kits.

Metabolic syndrome was defined based on the ATPIII-2005 diagnostic criteria. Raised serum triglyceride ( $\geq 150 \mathrm{mg} / \mathrm{dl})$, reduced HDL cholesterol $(<40 \mathrm{mg} / \mathrm{dl}$ in male and $<50 \mathrm{mg} / \mathrm{dl}$ in female $)$, and raised blood pressure (systolic $\mathrm{BP} \geq 130$ and/or diastolic $\mathrm{BP} \geq 85 \mathrm{~mm} \mathrm{Hg}$ ) in addition to central obesity and previously diagnosed type 2 diabetes or raised fasting plasma glucose (FPG) $\geq 100 \mathrm{mg} / \mathrm{dL}$, and waist circumference: Male $\geq 102 \mathrm{~cm}$, Female $\geq$ $88 \mathrm{~cm}$ has been considered for MetS definition [6]. A detailed description of the baseline characteristics of the research population and prevalence of MetS components in older adults has been reported in a previous study [6].

This research has been approved by the Research Committee of Babol University of Medical Sciences on Feb 9, 2016 as registration code 9441623. 
Statistical analysis. Data was analyzed using SPSS-18 package. Receiver operating characteristic (ROC) curve and area under the curve (AUC) were used to determine the value of anthropometric indices for predicting metabolic syndrome. The area under the curve was reported with $95 \%$ confidence interval to compare ROC curves of different anthropometric indices. T-test was used to compare different values in people with and without metabolic syndrome. The significance level for all tests was considered as $\mathrm{p}<0.05$.

\section{RESULTS}

A total of 1488 elderly people with a mean age of $69.7 \pm 7.30$ years (range of $60-92$ years) were included in this study; of whom 826 were male $(55.51 \%)$ and 662 were female (44.48\%); and 128 individuals were excluded. Based on the criteria of ATPIII-2005, the MetS was present in 1065 $(71.57 \%)$ of the participants and absent in 423 $(28.42 \%)$. Anthropometric indices of the study population based on gender and MetS are shown in Table 1. The mean age of people with MetS was significantly lower than people without it $(p<0.001)$, this difference was seen in both sexes.

The mean BMI, waist circumference, hip circumference, waist-to-hip ratio, waist-to-height ratio, AVI, and CI were higher in participants with MetS than others, and this difference was significant in both sexes $(p<0.001)$. There was no difference between elderly people with and without MetS in terms of mean neck circumference $(p=0.10)$.

ROC curve and AUC for various anthropometric indicators in predicting of MetS are shown in Figure 1 and Table 2. In men and women, the highest area under the curve was related to waist circumference followed by AVI and waist-to-height ratio, respectively. All anthropometric indices in women had a higher AUC than the men. The highest AUC in total population was related to waist-to-height ratio (0.786; 95\% CI: 0.76-0.81) followed by BMI (0.746; 95\% CI: 0.71-0.77), AVI (0.745; 95\% CI: 0.71-0.77), and waist circumference $(0.743$; $95 \%$ CI: $0.71-0.77)$.

\section{DISCUSSION}

This study showed that metabolic syndrome had a prevalence of about $71.6 \%$ in older people, based on the ATPIII criteria; furthermore, another research related to the same cohort project of AHAP in which the prevalence of MetS and its components among elderly population of Amirkola has been reported based on the four diagnostic criteria including ATP III-2005, ATP III-2001, International Diabetes Federation (IDF) and Iranian definitions revealed that $57.4 \%$ of males and $89.8 \%$ of females in this region had MetS [6]. These values are higher than other studies such as prevalence of $32.5 \%$ in Marbou et al. research in Cameroon conducted on adult population aged 20 and over [27]; and Sigit et al. research in which $39.0 \%$ of study population - individuals aged 45-65 years in Indonesia and $29.2 \%$ of Dutch population in the Netherland had MetS [7]. In Ben-Yacov's study on adults aged 18-69 years in rural Uganda, the prevalence of MetS was reported 19.1\% [8]. A systematic review and meta-analysis in Iran revealed that according to the International Diabetes Federation and World Health Organization diagnostic criteria, the prevalence of MetS were 38\% (95\% CI: 32-43) and $30 \%$ (95\% CI: 7-53), respectively [28]. This difference can be due to a difference in demographic, socioeconomic, lifestyle behaviors including nutritional pattern and physical activity, and difference in prevalence of cardiometabolic risk factors such as hypertension, hyperlipidemia, and diabetes in various regions. Furthermore, different diagnostic criteria might be used in different studies [29].

Neck circumference has not showed a significant difference between older adults who had MetS in comparison with those who did not have MetS. Ataie-Jafari in a systematic review and meta-analysis demonstrated a significant association between NC and other cardiometabolic risk factors; and pointed to a research in which an odds ratio of 11.53 and 7.69 for high NC in prediction of MetS presence in elderly men and women has been reported [21]. Baena et al. study on people aged 35-74 years concluded that NC was significantly and independently associated with adverse cardiometabolic risk factors in adult men and women and also represented optimal values for identifying those individuals who might have a combination of two or three of the cardiometabolic risk factors including insulin resistance, low HDL, elevated blood pressure, and high triglycerides [22]. Considering a different distribution of MetS between men and women and difference in anthropometric measures between the two sexes, it seems that in this research in association between neck circumference and metabolic syndrome, the gender might act as a confounding factor; resulted in non-significant difference in total population. 
Table 1

Anthropometric indices of older adults based on gender and metabolic syndrome

\begin{tabular}{|c|c|c|c|c|c|c|c|c|c|}
\hline \multirow[b]{2}{*}{ Variables } & \multicolumn{3}{|c|}{ Male } & \multicolumn{3}{|c|}{ Female } & \multicolumn{3}{|c|}{ Total } \\
\hline & $\begin{array}{c}\text { M.S + } \\
\text { Mean } \pm \text { SD } \\
(\mathrm{n}=470)\end{array}$ & $\begin{array}{c}\text { M.S - } \\
\text { Mean } \pm \text { SD } \\
(\mathrm{n}=356)\end{array}$ & $\mathrm{P}$ & $\begin{array}{c}\text { M.S + } \\
\text { Mean } \pm \text { SD } \\
(\mathrm{n}=595)\end{array}$ & $\begin{array}{c}\text { M.S - } \\
\text { Mean } \pm \text { SD } \\
(\mathrm{n}=67)\end{array}$ & $\mathrm{p}$ & $\begin{array}{c}\text { M.S }+ \\
\text { Mean } \pm \text { SD } \\
(n=1065)\end{array}$ & $\begin{array}{c}\text { M.S }- \\
\text { Mean } \pm \text { SD } \\
(\mathrm{n}=423)\end{array}$ & $\mathrm{P}$ \\
\hline Age & $68.9 \pm 7.2$ & $70.5 \pm 7.8$ & .001 & $68.2 \pm 6.7$ & $68.7 \pm 7.8$ & -0.001 & $68.5 \pm 6.9$ & $70.3 \pm 7.9$ & $<0.001$ \\
\hline Weight (Kg) & $72.4 \pm 11.7$ & $64.1 \pm 10.3$ & $<0.001$ & $66.32 \pm 11.4$ & $55.1 \pm 11.3$ & $<0.001$ & $69.02 \pm 11.9$ & $62.7 \pm 11$ & $<0.001$ \\
\hline Height & $162.8 \pm 6.8$ & $162.1 \pm 6.7$ & 0.13 & $151.4 \pm 6.1$ & $149.1 \pm 5.5$ & $<0.001$ & $156.4 \pm 6.3$ & $160 \pm 8.0$ & $<0.001$ \\
\hline BMI & $27.2 \pm 3.7$ & $24.3 \pm 3.4$ & $<0.001$ & $.89 \pm 4.5$ & $24.7 \pm 4.6$ & $<0.0$ & $28.1 \pm 4.2$ & $24.4 \pm 3.6$ & $<0.001$ \\
\hline WC & $98.3 \pm 9.35$ & $90.2 \pm 9.03$ & $<0.001$ & $97.72 \pm 9.8$ & $84.7 \pm 9.3$ & $<0.001$ & $98.01 \pm 9.6$ & $89.3 \pm 9.2$ & $<0.001$ \\
\hline $\mathrm{HC}(\mathrm{cm})$ & $101.7 \pm 7.39$ & $97.29 \pm 7.08$ & $<0.001$ & $106.2 \pm 9.5$ & $97.1 \pm 9$ & $<0.001$ & $104.2 \pm 8.9$ & $97.2 \pm 7.4$ & $<0.001$ \\
\hline $\mathrm{N}$ & $7 \pm 2.8$ & $37.8 \pm 2.5$ & .001 & $5.63 \pm 2.7$ & $33.3 \pm 2.7$ & $<0$. & $37.47 \pm 3.4$ & $37.17 \pm 3$ & 0.10 \\
\hline WHR & $0.96 \pm 0.05$ & $0.92 \pm 0.05$ & $<0.001$ & $0.9 \pm 0.06$ & $0.8 \pm 0.06$ & $<0.001$ & $0.94 \pm 0.06$ & $0.91 \pm 0.06$ & $<0.001$ \\
\hline & $5 \pm 0.05$ & $0.5 \pm 0.05$ & $<0.001$ & $0.6 \pm 0.06$ & $0.5 \pm 0.06$ & $<0.001$ & $0.6 \pm 0.06$ & $0.5 \pm 0.05$ & $<0.001$ \\
\hline & $19.5 \pm 3.6$ & $16.4 \pm 3.1$ & $<0.001$ & $19.3 \pm 3.8$ & $14.6 \pm 3.2$ & $<0.001$ & $19.4 \pm 3.7$ & $16.2 \pm 3.2$ & $<0.001$ \\
\hline $\mathrm{CI}$ & $1.35 \pm 0.07$ & $1.31 \pm 0.07$ & $<0.001$ & $1.3 \pm 0.8$ & $1.2 \pm 0.9$ & $<0.001$ & $1.35 \pm 0.07$ & $1.31 \pm 0.08$ & $<0.001$ \\
\hline
\end{tabular}

MetS+: with Metabolic Syndrome; MetS-: without Metabolic Syndrome; BMI: Body Mass Index; WC: Waist Circumference; HP: Hip Circumference; NC: Neck Circumference, WHR: Waist to Hip Ratio, WHtR: Waist to Height Ratio; AVI: Abdominal Volume Index; CI: Conicity Index.
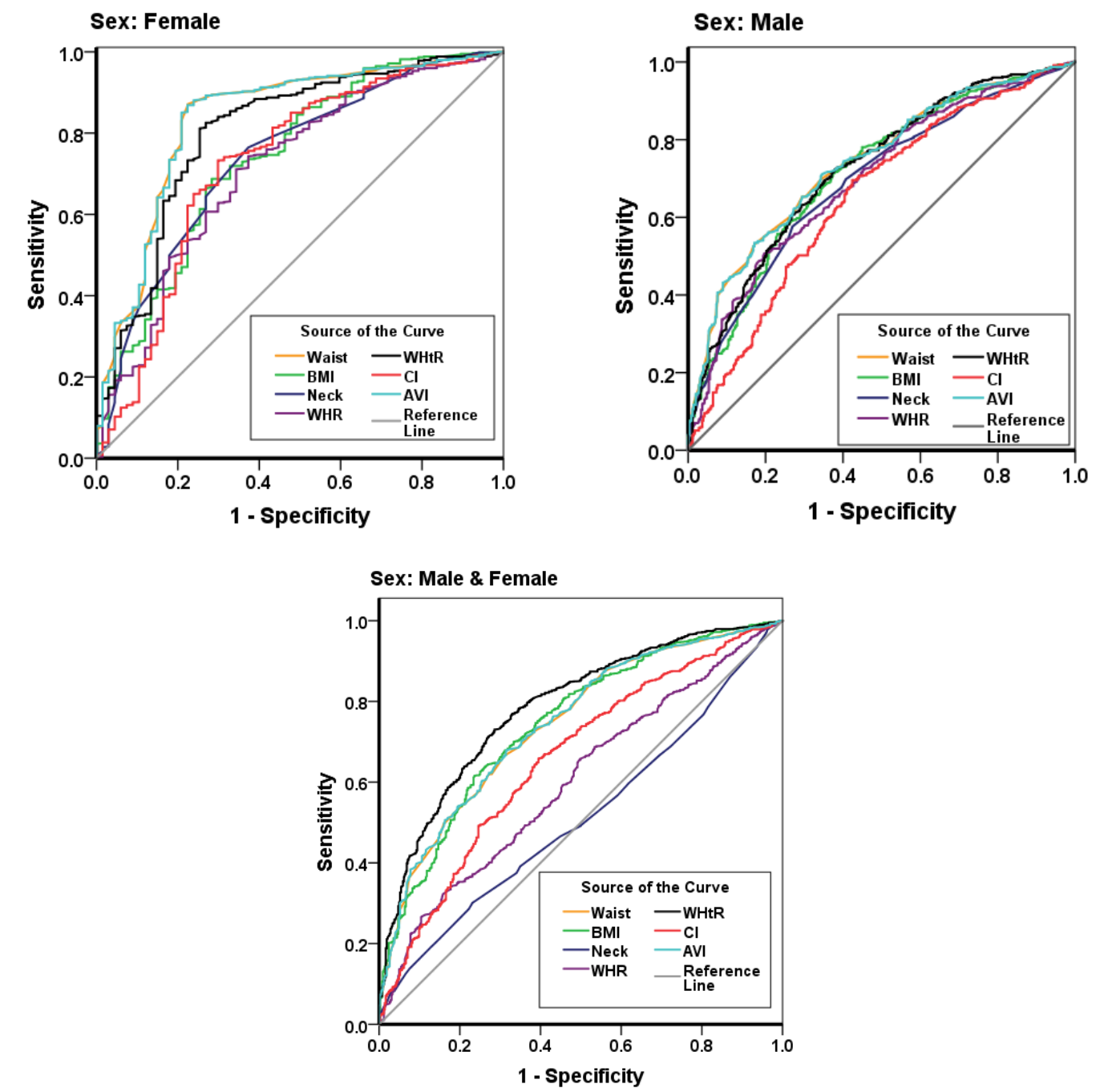

BMI: Body Mass Index; WC: Waist Circumference; HP: Hip Circumference; NC: Neck Circumference, WHR: Waist to Hip Ratio, WHtR: Waist to Height Ratio; AVI: Abdominal Volume Index; CI: Conicity Index.

Figure 1. The ROC curve and the AUC of different anthropometric indices for predicting of metabolic syndrome in older adults in two sexes. 
Table 2

Area under the curve for the value of anthropometric indices in predicting of metabolic syndrome in older adults divided in two sexes

\begin{tabular}{|c|c|c|c|c|c|c|}
\hline \multirow{2}{*}{ Variables } & \multicolumn{2}{|c|}{ Male } & \multicolumn{2}{c|}{ Female } & \multicolumn{2}{c|}{ Total } \\
\cline { 2 - 7 } & AUC $(95 \% \mathrm{CI})$ & P-value & AUC $(95 \% \mathrm{CI})$ & P-value & AUC $(95 \% \mathrm{CI})$ & P-value \\
\hline BMI $\left(\mathrm{kg} / \mathrm{m}^{2}\right)$ & $0.715(0.68-0.75)$ & 0.001 & $0.740(0.67-0.80)$ & 0.001 & $0.746(0.71-0.77)$ & 0.001 \\
\hline WC $(\mathrm{cm})$ & $0.740(0.70-0.77)$ & 0.001 & $0.837(0.78-0.89)$ & 0.001 & $0.743(0.71-0.77)$ & 0.001 \\
\hline NC $(\mathrm{cm})$ & $0.692(0.65-0.72)$ & 0.001 & $0.739(0.67-0.80)$ & 0.001 & $0.513(0.48-0.54)$ & 0.418 \\
\hline WHR & $0.698(0.66-0.73)$ & 0.001 & $0.715(0.64-0.78)$ & 0.001 & $0.602(0.57-0.63)$ & 0.001 \\
\hline WHtR & $0.725(0.69-0.75)$ & 0.001 & $0.805(0.74-0.86)$ & 0.001 & $0.786(0.76-0.81)$ & 0.001 \\
\hline AVI & $0.739(0.70-0.77)$ & 0.001 & $0.837(0.78-0.89)$ & 0.001 & $0.745(0.71-0.77)$ & 0.001 \\
\hline CI & $0.652(0.61-0.69)$ & 0.001 & $0.725(0.68-0.80)$ & 0.001 & $0.658(0.62-0.68)$ & 0.001 \\
\hline
\end{tabular}

BMI: Body Mass Index; WC: Waist Circumference; HP: Hip Circumference; NC: Neck Circumference, WHR: Waist to Hip Ratio, WHtR: Waist to Height Ratio; AVI: Abdominal Volume Index; CI: Conicity Index.

In the present research, WHtR, BMI, AVI, and WC had the highest value to predict MetS, respectively. In Quaye et al. study BMI had the largest AUC for MetS [0.85 (0.79-0.91)]; and BMI and WC showed similar AUCs in predicting the presence of a cluster of two or more non-WC components for MetS [30]. In Zhang et al. research, the AUC values belonged to WHtR were 0.872 in Kazakh males and 0.804 in Kazakh females [31], which were higher than those $(0.725$ for men and 0.805 for women) observed in our study. Taking height into account, WHtR may be a better predictor of cardiometabolic risk and may more accurately reflect the MetS and MetS components. In Obeidat's study, AUC for waist circumference in men was reported 0.851, however, AUC for WHtR was 0.85 , and AUC for BMI was 0.83. In women, AUC for $\mathrm{WC}, \mathrm{WHtR}$, and BMI were 0.866, 0.872, and 0.831 , respectively; and concluded that both WHtR and WC had the strongest predictive power for identifying individuals with MetS in both sexes. In addition to, WHtR has been reported to be the best indicator of central obesity in women and individuals of short stature [18].

In our study, Abdominal Volume Index showed a high AUC for predicting MetS. Quaye showed a better performance of AVI and CI compared to BMI in prediction of MetS and its components in females [30]. Suliga et al. evaluated correlation of six anthropometric indices to predict MetS risk in Polish adults aged 37-66 years; and resulted that WHtR and Clinica Universidad de Navarra-body adiposity estimator in males and WHtR and body roundness index in females had the highest odds ratios for occurrence of MetS [32].

The prediction of cardiometabolic risk in older men or women is essential for selecting candidates requiring early preventive strategies [33]. Considering this proposition that the cardiometabolic consequences of obesity are less associated with overall adiposity than visceral adiposity, those measures of adiposity which reflect body fat distribution [30], seem to be more valuable.

The most strength point of this study is selecting a large sample of older adults aged 60 and over and assessment the value of seven anthropometric parameters (BMI, WC, NC, WHR, WHtR, AVI and CI) to identify the occurrence of metabolic syndrome in this population. For limitation of this research we can mention to the study design that did not allow us to examine the long-term value of anthropometric parameters for predicting metabolic syndrome. In addition to, considering the specificity of study population, the results may be not applicable to other age groups or races.

\section{CONCLUSION}

This study showed that waist-to-height ratio had a better diagnostic value for metabolic syndrome in older adults, followed by BMI, AVI, waist-tohip ratio, and neck circumference. However, for further certainty, several other studies in different age groups are necessary.

Introducere. Prevalența obezității și a sindromului metabolic (MetS) este în creștere. Programele de prevenție au nevoie de o metodă simplă și eficientă pentru a prezice MetS. Scopul studiului a fost de a compara diferiți indici antropometrici pentru a putea prezice MetS la adulți.

Materiale și metode. A fost realizat un studiu transversal parte din Cohorta Amirkola Health and Ageing Project (2011-2016). 1488 de pacienți vârstnici 
(60-92 ani) au fost înrolați. Datele au fost colectate folosind un chestionar. Au fost măsurate înălțimea, greutatea, circumferința taliei, circumferința şoldului, a gâtului, indicele de masă corporală, raportul talie/înălțime, indexul volumului abdominal (AVI), indexul de conicitate. Testul $t$-Student și curba ROC au fost utilizate pentru analiza datelor.

Rezultate. Bazându-ne pe criteriile ATPIII-2005 prevalența MetS a fost de 71,57\%. Prevalența la femei a fost mai mare decât la bărbați. Toți parametrii antropometrici au fost mai mari la pacienții cu MetS, mai puțin circumferința gâtului. Aria de sub curba ROC pentru raportul talie/înălțime a fost cel mai bun pentru prezicerea MetS (0,786; 95\% CI: 0,76-0,81), urmat de BMI (0,746; 95\% CI: 0,71-0,77), AVI $(0,745 ; 95 \%$ CI: 0,71-0,77) și circumferința taliei $(0,743$; 95\% CI: 0,71-0,77).

Concluzii. Raportul talie/inălțime a fost cel mai bun pentru prezicerea MetS la pacienții vârstnici.

Correspondence to: Reza Ghadimi, MD, PhD, Social Determinants of Health Research Center, Health Research Institute, Babol University of Medical Sciences, Ganj Afrooz Ave, Babol, Iran. Tel: +98-11-32190557

E-mail: rezaghadimi@yahoo.com

Acknowledgment: This study was financially supported by vice-chancellor of research and technology of Babol University of Medical Sciences.

Conflict of interest disclosure: There is no conflict of interest.

\section{REFERENCES}

1. LARTEY ST., MAGNUSSEN CG., SI L., BOATENG GO., DE GRAAFF B., BIRITWUM RB., et al. Rapidly increasing prevalence of overweight and obesity in older Ghanaian adults from 2007-2015: Evidence from WHO-SAGE Waves 1 and 2. PloS one. 2019; 14: e0215045.

2. GHADIMI R. ASGHARZADEH E., SAJADI P. Obesity among Elementary Schoolchildren: A Growing Concern in the North of Iran, 2012. International Journal of Preventive Medicine. 2015; 6:99.

3. VAISI-RAYGANI A., MOHAMMADI M., JALALI R., GHOBADI A., SALARI N. The prevalence of obesity in older adults in Iran: a systematic review and meta-analysis. BMC Geriatrics. 2019; 19:371.

4. CERCATO C., FONSECA FA. Cardiovascular risk and obesity. Diabetology \& Metabolic Syndrome. 2019; 11:74.

5. CSIGE I., UJVAROSY D., SZABO Z., LORINCZ I., PARAGH G., et al. The Impact of Obesity on the Cardiovascular System. Journal of diabetes research, 2018; 2018:3407306-3407306.

6. BIJANI A., HOSSEINI SR., GHADIMI R., MOUODI S. Association of metabolic syndrome and its components with survival of older adults. Int J Endocrinol Metab. 2020; 18: e91837.

7. SIGIT FS., TAHAPARY DL., TROMPET S., SARTONO E., WILLEMS VAN DIJK K., et al. The prevalence of metabolic syndrome and its association with body fat distribution in middle-aged individuals from Indonesia and the Netherlands: a crosssectional analysis of two population-based studies. Diabetology \& Metabolic Syndrome, 2020; 12:2.

8. BEN-YACOV L., AINEMBABAZI P., STARK AH., KIZITO S., BAHENDEKA S. Prevalence and sex-specific patterns of metabolic syndrome in rural Uganda. BMJ NPH Epub. 2020; 0:1-7

9. KASSI E., PERVANIDOU P., KALTSAS G., CHROUSOS G. Metabolic syndrome: definitions and controversies. BMC medicine. 2011; 9:48.

10. BORGA M., WEST J., BELL JD., HARVEY NC., ROMU T., HEYMSFIELD SB., DAHLQVIST LEINHARD O. Advanced body composition assessment: from body mass index to body composition profiling. Journal of investigative medicine: the official publication of the American Federation for Clinical Research. 2018; 66:1-9.

11. KULlBERG J., BRANDBERG J., ANGELHED JE., FRIMMEL H., BERGELIN E., STRID L., et al. Whole-body adipose tissue analysis: comparison of MRI, CT and dual energy X-ray absorptiometry. Br J Radiol. 2009; 82:123-130.

12. TRAN NTT., BLIZZARD CL., LUONG KN., TRUONG NLV., TRAN BQ., OTAHAL P., et al. The importance of waist circumference and body mass index in cross-sectional relationships with risk of cardiovascular disease in Vietnam. PloS one. 2018; 13: e0198202-e0198202.

13. ORTEGA FB., SUI X., LAVIE CJ., BLAIR SN. Body Mass Index, the Most Widely Used But Also Widely Criticized Index: Would a Criterion Standard Measure of Total Body Fat Be a Better Predictor of Cardiovascular Disease Mortality?. Mayo Clinic proceedings. 2016; 91:443-455.

14. GHESMATY SANGACHIN M., CAVUOTO LA., WANG Y. Use of various obesity measurement and classification methods in occupational safety and health research: a systematic review of the literature. BMC Obesity. 2018; 5:28.

15. HOSSEINI SR., SAJJADI P., JAMALI S., NOREDDINI HG., GHADIMI R., BIJANI A. The relationship between body mass index and bone mineral density in older people. Journal of Babol University of Medical Sciences. 2014; 16:14-22 [in Persian]. Available from: http://jbums.org/article-11-4824-fa.html. 
16. PALEY CA., JOHNSON MI. Abdominal obesity and metabolic syndrome: exercise as medicine?. BMC sports science, medicine \& rehabilitation. 2018; 10:7-7.

17. PINHO CPS, Diniz ADS, DE ARRUDA IKG., LEITE APDL., PETRIBU MMV., RODRIGUES IG. Predictive models for estimating visceral fat: The contribution from anthropometric parameters. PLoS ONE. 2017; 12: e0178958.

18. OBEIDAT AA., AHMAD MN., HADDAD FH., AZZEH FS. Evaluation of several anthropometric indices of obesity as predictors of metabolic syndrome in Jordanian adults. Nutr Hosp. 2015; 32:667-677.

19. GIERACH M., GIERACH J., EWERTOWSKA M., ARNDT A., JUNIK R. Correlation between Body Mass Index and Waist Circumference in Patients with Metabolic Syndrome. ISRN endocrinology. 2014; 2014:514589-514589.

20. YOO E-G. Waist-to-height ratio as a screening tool for obesity and cardiometabolic risk. Korean Journal of Pediatrics. 2016; 59:425-431.

21. ATAIE-JAFARI A., NAMAZI N., DJALALINIA S., CHAGHAMIRZAYI P., ABDAR ME., ZADEHE SS., et al. Neck circumference and its association with cardiometabolic risk factors: a systematic review and meta-analysis. Diabetology \& Metabolic Syndrome. 2018; 10:72.

22. BAENA CP., LOTUFO PA., FONESCA MG., SANTOS IS., GOULART AC., BENSENOR IM. Neck Circumference Is Independently Associated with Cardiometabolic Risk Factors: Cross-Sectional Analysis from ELSA-Brasil. Metab Syndr Relat Disord. 2016; 14:145-153.

23. WANG H., LIU A., ZHAO T., et al. Comparison of anthropometric indices for predicting the risk of metabolic syndrome and its components in Chinese adults: a prospective, longitudinal study. BMJ Open. 2017; 7:e016062.

24. HOSSEINI SR., CUMMING RG., KHEIRKHAH F., NOOREDDINI H., BIJANI A., MIKANIKI E., et al. Cohort profile: The Amirkola Health and Aging Project. Int J Epidemiol. 2014; 43:1393-1400.

25. PURNELL JQ. Definitions, Classification, and Epidemiology of Obesity. [Updated 2018 Apr 12]. In: Feingold KR, Anawalt B, Boyce A, et al., editors. Endotext [Internet]. South Dartmouth (MA): MDText.com, Inc.; 2000-. Available from: https://www. ncbi.nlm.nih.gov/books/NBK279167/

26. VIKRAM GOWDA KP. Abdominal volume index and conicity index in predicting metabolic abnormalities in young women of different socioeconomic class. International Journal of Medical Science and Public Health Int. 2016; 5(7):1452-6.

27. MARBOU WJT., KUETE V. Prevalence of Metabolic Syndrome and Its Components in Bamboutos Division's Adults, West Region of Cameroon. Biomed Res Int. 2019; 2019:9676984.

28. DALVAND S., NIKSIMA SH., MESHKANI R., GHANEI GHESHLAGH R., SADEGH-NEJADI S., KOOTI W., et al. Prevalence of Metabolic Syndrome among Iranian Population: A Systematic Review and Meta-analysis. Iranian Journal of Public Health. 2017; 46:456-467.

29. BIJANI A., HOSSEINI S.R., GHADIMI R., MOUODI S. Association of Metabolic Syndrome and Its Components with Survival of Older Adults. Int J Endocrinol Metab. 2020; 18 (1): e91837.

30. QUAYE L., OWIREDU WKBA., AMIDU N., DAPARE PPM., ADAMS Y. Comparative Abilities of Body Mass Index, Waist Circumference, Abdominal Volume Index, Body Adiposity Index, and Conicity Index as Predictive Screening Tools for Metabolic Syndrome among Apparently Healthy Ghanaian Adults. Journal of Obesity. 2019; 2019:8143179.

31. ZHANG XH., ZHANG M., HE J., YAN YZ., MA JL., WANG K., et al. Comparison of Anthropometric and Atherogenic Indices as Screening Tools of Metabolic Syndrome in the Kazakh Adult Population in Xinjiang. Int J Environ Res Public Health. 2016; 13:428.

32. SULIGA E., CIESLA E., GLUSZEK-OSUCH M., ROGULA T., GLUSZEK S., KOZIEL D. The Usefulness of Anthropometric Indices to Identify the Risk of Metabolic Syndrome. Nutrients. 2019; 2598.

33. ABULMEATY MMA., ALMAJWAL AM., ALMADANI NK., ALDOSARI MS., ALNAJIM AA., ALI SB., et al. Anthropometric and central obesity indices as predictors of long-term cardiometabolic risk among Saudi young and middle-aged men and women. Saudi medical journal. 2017; 38:372-380.

Received $2^{\text {nd }}$ March 2020 